UDC: $33: 336.2$

JEL Classification: E5, G2

DOI: 10.15587/2312-8372.2020.201120

\section{Abubakar A. M., Daneji B. A., Muhammed A. I. Chekene I.-A. B.}

\title{
DRIVING FASTER FINANCIAL INCLUSION IN DEVELOPING NATIONS
}

Об'єктом дослідження є альтернативна стратегія, яка могла б сприяти більш швидкому досягненню високого рівня фінансової доступності для країн, що розвиваються. Це важливо, оскільки фінансова ізоляція була визначена як один з факторів, що стримують розвиток країн, що розвиваються. Більшість з них зробили узгоджені зусилля для стимулювання фінансової доступності, але через погану реалізацію $i$, найчастіше, через неправильну стратегію, спрямовану на прискорення доступності, більшість краӥн, що розвиваються, мають дуже високі показники ізолящіі. Дана проблема розглядається на прикладі Нігерї, однієї з таких країн, що розвиваються, яка після 4 років реалізачї стратегї доступності фінансової сфери, в 2012 р. повідомила про $68 \%$ відчуження, а до 2020 р. - $80 \%$.

В ході даного дослідження використовувалася літературна тріангулящія для вилучення пращездатних альтернатив, які були представлені на дискусійних панелях з практичним знанням найгірших геополітичних зон в Нігерї. Згідно з різними звітами про розширену фінансову доступність в Нігерї̈ (EFInA), це Північно-східна і Північно-західна геополітичні зони.

В результаті даного дослідження показано, що в оновленій стратегї використовується стара система стратегій виключення, яка дозволила виключити більше людей на числовій основі, ніж в базовий рік реалізацї стратегії. Таким чином, в цьому дослідженні рекомендується стратегія поштовху шляхом переорієнтацї розуму виключених для прискорення фінансової доступності. Швидка доступність, у крайньому випадку, скоріше, ніж темпи приросту населення, приведе до кращого індексу фінансової доступності та по-справжньому прискореного економічного зростання.

В майбутнъому пропонований підхід являє собою емпіричне дослідження фактичних виключених членів в основних вузьких спільнотах.

Ключові слова: країни, що розвиваються, фінансова ізолящія, фінансова доступність, фінансові послуги, банки Нiгеріi.

Received date: 16.01.2020

Accepted date: 21.02.2020

Published date: 30.04 .2020
Copyright (C) 2020, Abubakar A. M., Daneji B. A., Muhammed A. I., Chekene I.-A. B. This is an open access article under the CC BY license (http://creativecommons.org/licenses/by/4.0)

\section{Introduction}

Financial Inclusion (FI) has been recognised as a potent factor for accelerating economic growth of nations. It has been observed that access to financial services has a critical role to play in reducing extreme poverty, boosting and building sustainable economic growth, and achieving rapid development [1-3]. In order to accelerate this economic growth of nations, the developmental policies of international bodies, such as the International Monetary Fund (IMF) [4] have been revisited and reviewed to provide the much needed support to achieve their developmental goals. The African Development Bank (AfDB) [5] also advocates an all-encompassing financial inclusion which, would mobilize much savings that could be used for investment by entrepreneurs thereby reducing poverty, unemployment and crime tendencies among citizens. This, the AfDB further advocates, would manifest into an increasing standard of living of the poor rural populace. The author of [6] submits that FI leads to faster and equitable growth of nations. While authors of [7] posits FI as leading to financial deepening. This realisation of the potentiality of
FI drove a host of developing nations to the Maya 2011 convention where they committed to reducing financial exclusion to at most $20 \%$ by the year 2020 . Nigeria, one of the Maya declaration signatories commenced its inclusion strategy by 2012 [8] while Zimbabwe, another signatory, commenced its inclusion strategy implementation in 2016 [7] both with the same agreed target year of 2020 .

With just a year to D-day, the envisaged target remains far out of sight even for the diligent countries. Yet direct inclusionary strategy literature remains scant and unutilised for the available few. While a major strand of extant literature dwell on components of FI only a few such as the author of [9], motivated by his position at the commonwealth secretariat, took a look at a strategy for inclusion, in his case specifically, of women. The author of [10] conducted a literature review to glean out best practise strategies so that nations can borrow to boost their financial inclusion. Additionally and considering the Nigerian inclusionary strategy, the review report, conducted between October 2017 and June 2018 [8], did not indicate an awareness of any alternative perspective to strategy for inclusion apart from the practitioners'. Let's contribute 
to this minor strand of extant literature, in the spirit of [10], for nations to adopt best practise inclusionary strategies. This should serve as the catalyst to drive faster achievement of financial inclusion in developing nations. Additionally, to increase the possibility of usage by policy makers, let's ensure presentations in visible mediums. Let's achieve these goals through a triangulation of extant literature to extract workable ideas that were presented at expert forums for discussions to identify alternative strategies that report here. This report consists of an overview of Financial Inclusion and the Nigerian, as a developing nation, Financial Inclusion Strategy review and conclusions.

Communal existence involves systems through which individuals serve their needs. Our financial needs, as members of a society, are met through formal financial systems in different sectors of the economy. This can only happen if citizens are connected to the system; that is being financially included. It is a right of the citizens to be included, as observed by [10] and it is beneficial to the community to ensure the inclusion of all members of a society $[5,6]$. FI is a situation when an individual has access to the services offered on the financial systems in different sectors of a community. Both the author of [9] and those of [11] believe that FI is not just access to financial outlets but there should also be usage for an acceleration of economic progress to be observed. The author of [9] further adds that quality of the services offered determine constant usage which is more potent for the sought for economic progress. In the views of the author of [12], the quality services offered must also be affordable if the community is to ensure the inclusion of the low income segment of the society who constitute the often most excluded. The authors of [11] further assert that citizens have to be included formally for there to be a true acceleration of economic progress. To conclude, the authors of [7], surmise that it is difficult to define the term because of this multifaceted nature and that this leads to a multipronged approach of different Governments. The perspective of the African Development Bank (AfDB) on FI is the most precise, when it states that $\ll$ FI includes all initiatives aimed at making formal financial services available, accessible and affordable...» [5]. A broader definition is given by Central Bank of Nigeria $(\mathrm{CBN})$ as «financial inclusion is achieved when adult Nigerians have easy access to a broad range of formal financial services that meet their needs at affordable costs» [8]. Both definitions indicate the required formalness of the inclusion and that it should be accessible and affordable. Let's hasten to add that there should be motivational policies to promote usage as a most potent strategy to influence inclusion through overcoming voluntary barriers.

Much of the growing literature on FI dwell on what the authors of [13] term as the corollary of inclusion that is exclusion. The thrust is that attention should be centred on the excluded to bring them back into the fold. By identifying the barriers that creates exclusion, such authors, hope to point out what needs to be removed to achieve inclusion. On his part, the author of [14] posits two sides of demand and supply from where financial exclusion emanates. Literacy level, remote areas, disadvantaged social group, and informal sources of credit are on the demand side. On the supply side is a distance from banks, inappropriate products, inconvenient timing, attitude of staff, identification requirements and transactions cost.
To the authors of [2] these barriers for financial inclusion are cost of the financial services, travel distance to get the services, cumbersome paper work involved and lack of demand for the financial products or services. The author of [15] listed income, physical access, financial literacy, affordability and eligibility as the stimulant to financial exclusion. While the authors of [12] prefer to view these barriers as making up voluntary and involuntary exclusions. The voluntary are those that motivate individual to refuse inclusion while the involuntary are those factors that deny individuals from inclusion even when there is a desire to be included. For instance the authors of [16], report that while people were enthusiastic about e-money only about $10-25 \%$ actually got on mostly due to lack of trust for the institutions and poor mobile connectivity. A take away here is that a good strategist must play the Devil's advocate to provide a solution to every fathomable problem to successfully achieve set objectives.

Thus, object of research is an alternative strategy that could drive a faster achievement of higher rate of financial inclusion for developing nations. Additionally, to increase the possibility of usage by policy makers, let's ensure presentations in visible mediums. And the aim of this article is to drive a faster financial inclusion for developing nations for the achievement of the desired position by the stated date agreed on by the Maya convention signatories.

\section{Methods of research}

The design of this study is Historical with the developing nations of the world as its population. It was conducted in a descriptive style on Nigeria as a conveniently selected developing nation. This decision was informed from the fact of the high population of the country, the high population growth rate, its high financial exclusion rate, and its fervent desire to reduce the rate of exclusion. The study further delimits the geographical area of the study to the two geographical zones to the far north of the country for being the zones of highest financial exclusion in the country. The method adopted for the study is literature triangulation with expert discussion panels in the two selected zones. After all the research, a report is delivered as a narrative, for coherence, and a most potent strategy for the reduction of financial exclusion for developing nations is identified as a major conclusion.

\section{Research results and discussion}

Nigeria, as a Maya 2011 signatory, is one of the diligent nations that instituted a forum earlier than most other signatory nations. The forum was charged with the promulgation of strategies that can lead to the achievement of the Maya goals by the target date. The National Financial Inclusion Steering and Technical Committee (NFISTC) swung into action in 2012 [8], with a programme code named Vision 20:2020. That is to reduce financial exclusion to at most $20 \%$ by the year 2020 . The targeted services include payments, savings, credit, insurance, pension and capital market products. As stated by CBN [8], the major goal was to reduce the proportion of adult Nigerians that are financially excluded to $20 \%$ in year 2020 from its baseline figure of $46.3 \%$ in 2010 . Nigeria has made significant efforts in overcoming the inertia in the 
implementation of various initiatives in National Financial Inclusion Strategy, more still needs to be done to:

- strengthen coordination with states;

- incorporate women, disadvantaged groups, MSMEs (Micro, Small and Medium Enterprises) and geographical variations;

- strengthen existing monitoring and evaluation (M\&E) processes.

This necessitated the formation of a committee to review progress towards the target as at 2016, the halfway mark. The review committee consisted of core stakeholders who include:

1. Regulators; CBN, National Communication Commission (NCC), National Insurance Commission (NAICOM), Pension Commission (PENCOM), National Deposit Insurance Commission (NDIC) and Securities and Exchange Commission (SEC).

2. Financial services providers; Development Management Banks (DMBs), Microfinance Banks (MBs), Digital Financial Institutions (DFIs), Insurance Companies, Pension Funds Administrators and Assets Managers.

3. Other financial institutions; Mobile money operators and other financial technology companies.

4. Public sector institutions; Federal Ministries, National Identity Management Commission, Nigerian Postal Services and Government Agencies and programmes.

5. Development partners; Non-Governmental Organisations and Multilateral Agencies.

6. Distribution Actors; Mobile network providers, Interbank settlement providers and Super agents.

7. Users; Consumers and advocacy groups

The review acknowledged the lofty goals set for the National Financial Inclusion Strategy (NFIS) committee, which included 70 target recommendations, including targets for overall financial inclusion as well as targets for products, channels and enablers. It also confessed that «Six years» from implementation progress was impeded by «unforeseen socioeconomic factors» [8], that included the economic recessions and security situations in parts of Northern Nigeria, the slow take-up of Digital Financial Services (DFS) and limited roll out of National Identity Numbers. In passing, it is pertinent to note the discrepancy of the period of review in the term of reference and the period of review taken by the committee. However, the report went ahead to paint a hopeful picture for the next two years albeit with the same general strategies in place and nothing new to overcome the unforeseen socioeconomic barriers. It presented an overall target achievement, so far, as depicted in Fig. 1.

Fig. 1 shows an apparent success story for FI in Nigeria but a closer look indicates otherwise. It is originally from Enhanced Financial Inclusion Agency (EFInA) [17], whose definition of inclusion is broader to include the formal but unbanked and the informally included. Subsequent to this review date, the dismal performance is exposed further by a drop of the percentage inclusion in 2018 to $36.8 \%$ as reported in [18]. Discrepancies exist for how the latter two terms are to be measured as is noted in [17] that precise definitions for each category are not available for all years. Differences in data definitions may partially explain these findings. A working definition, the committee used, for the formal other include microfinance banks, insurance companies, pension funds and similar service providers. While the informal include Non-Governmental Organizations (NGOs) and financial cooperatives. One wonders how to get included here without being banked. The CBN [8] definition of FI recognises formal inclusion only. Additionally, the claim «Total inclusion rose from $53.7 \%$ in 2010 to $58.4 \%$ in 2016» is correct, taking the broader definition, but un-definitive because population growth outpaces inclusion rate in Nigeria. In that base year 31 million adults representing $36.5 \%$ of the population had access to any formal financial services however by 2016 , there were 40.1 million adults in Nigeria that were financially excluded representing $41.6 \%$ of the adult population as indicated by the authors of [19]. This means that more people were excluded by 2016, from any notion of inclusion, than in the base year. In fact, about 10.1 million more people were excluded. A higher proportion of this excluded population are in the northern part of the country. Perhaps, there is more population growth to the North than the Southern parts of the country as it is unthinkable for 10.1 million people to downright close down their accounts with Banks. A provided geopolitical breakdown (Fig. 2) of percentage inclusions shows even formal inclusions dropping for the three Northern geopolitical zones. This should have called for a special inclusion strategy for the folks up north as they represent the critical zones for national financial inclusion.

Nigeria financial inclusion rates over time, share of adult population (18+)

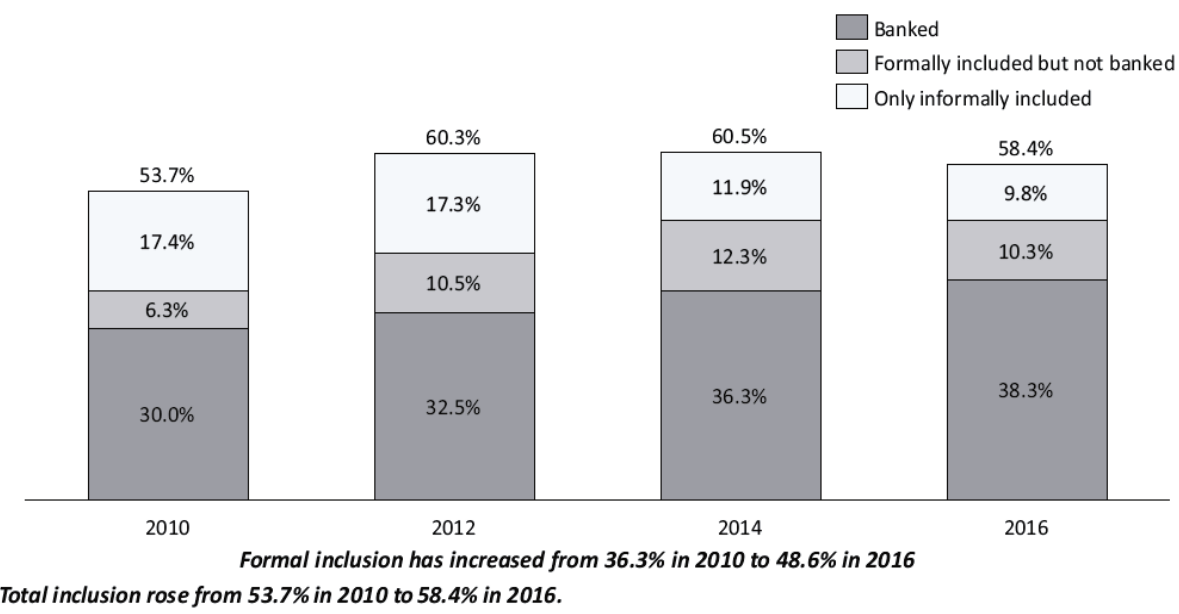

Fig. 1. The inclusion status of Nigeria by the date of review [8] 


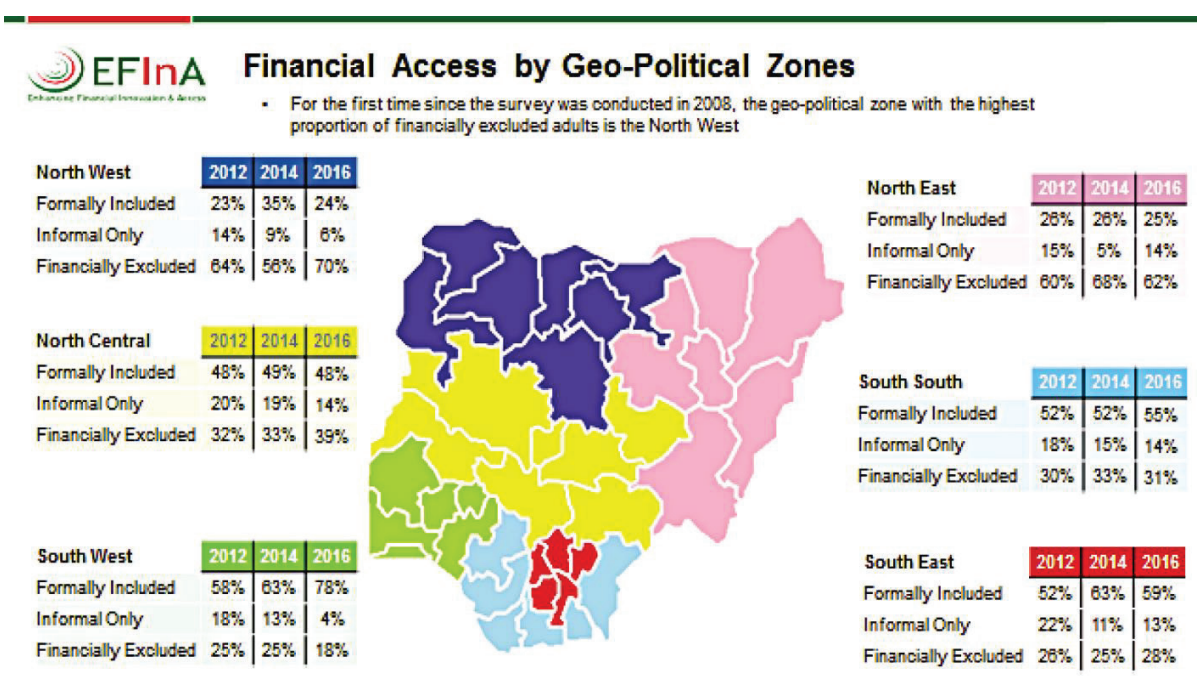

Fig. 2. Inclusion status by geopolitical zones [8]

The thrust of the refreshed NFIS (2018) is that the CBN provides a more efficient structure and a more effective management of the structure while other Stakeholders would be encouraged, policy-wise, to meet up with targets; mostly in the pull factors category. Its laudable for the CBN to provide such apex responsibility for it being just that; the apex financial agency. But then this thinking has restricted the robustness of the refreshed strategy by delimiting scope to finance. Ultimately, it is financial inclusion that is on the table but it is rather restrictive to think in this term only. The zonal inclusion picture clearly indicates the North-west and North-east Geo-political zones to be the most excluded zones in $\mathrm{Ni}$ geria. These are the zones also most associated with the worst case of poverty in the country. The author of [6] had indicated exclusion as a major socio-economic problem and advocated for poverty reduction to reduce financial exclusion. In building the structure, therefore, social institutions, such as the National Orientation Agency (NOA) and other northern Nigeria core interest organisation like the Northern Nigeria Development Corporation (NNDC), should be included as Stakeholders. The first institution reorients the mind to bestow trust on the financial system which can overcome voluntary exclusion while the second can help in driving a faster poverty eradication programme. In agreement with the authors of $[6,20]$ positioned that FI is about access and use of financial services. This calls for developing willingness and an ability to access and use financial services that can only developed by an appreciation of the none-financial factors that lead to exclusion. So while financial literacy modules, in our curricular of Management Sciences, are good enough for the long-run, an orientation and reorientation to recent developments would be more effective in reducing voluntary exclusions. When included, overcoming poverty is just a matter of time which has an attendant advantage for inclusion. In their study, the authors of [21], opined that a man, educated, and rich is more likely to be financially included than other wise.

That restrictive thinking has also led to a frenzy of activities, by the CBN, to drive capital availability. One of such activities is the recent upward review of Banks' Loan to Deposit Ratio (LDR), first to $60 \%$ then to
$65 \%$ and now expected to be raised to $70 \%$ by January 2020 [22]. This move has an attendant risk as observed in history. The authors of [23] mentioned that in the 1990s microfinance institutions were one of the tools used in enhancing financial inclusion all over the world. Nearly two decades thereafter, microfinance institutions began to show sign of problems as a result of high unpaid bills. Even the number of very poor clients began to go down. Stakeholders such as Financial Inclusion Experts Group (FIEG), the United Nations Capital Development Fund (UNCDF), the Better than Cash Alliance, the Bill \& Melinda Gates Foundation, and other private players (MasterCard, Visa and Crédit Suisse) concluded, during a G20 summit at Pittsburgh in 2009, that microfinance institutions failed to perform up to expectations after two decades [24]. Microfinance institutions were concentrating on lending which is only one aspects of inclusion among many. With these consequences in mind this overdrive policy of the $\mathrm{CBN}$, to motivate lending, becomes suspect. Its workability is also suspect up North of Nigeria given the socioeconomic factors decried by the initial inclusion committee. The northerners predominantly have a multi-dependants household in which members do not necessarily operate Bank accounts. In such a situation, an increased willingness of banks to lend can only pull in the bread winner of the household. This leaves the FI rate of the nation unchanged.

The authors of [25] observed that countries differ in their strategy and the policies geared towards financial inclusion. At the time India and China scored high in micro insurance, Kenya is doing well in mobile and electronic payments while Peru excelled in regulations and supervisions on savings and micro credit. These show that countries need to study their peculiarity and develop policies that will address the financial inclusion in their domain. The two geopolitical zones to the far north of Nigeria are critical to its overall FI. The North, being predominantly occupied by Muslims, is not exactly illiterate in the strict sense of word. They had their system of education, based on the predominant Islamic faith in the region, decades before the white man touched the shores of Nigeria. This refreshed strategy, therefore, could go a long way in achieving its target if it can overcome the 
political jingoism of Islamising the country to throw in a tactic of including Arabic alphabets albeit in Hausa and or any other indigenous language as an option in publications and operating languages of robotics. This addition, for instance, can influence the attitude of the Northerner towards the Automatic Teller Machines (ATMs) and the slow decker Takaful. In addition to the language medium, the inclusion of the National Orientation Agency, mentioned earlier, gains an added importance from the studies reported in [19, 26], both being on financial inclusion in Nigeria through Takaful - a form of insurance based on the Islamic faith. While the authors of [26] conducted their study in the North-west geopolitical zone of Nigeria, the authors of [19] conducted their own study in the North-east geopolitical zone and both studies advocated for a reorientation of the mind to adjust the attitude towards Takaful, specifically, and FI in general. This gives emphasis to reorientation of the mind towards the acceptance of modern phenomena, especially those that might be fully understood due to some inherent barriers.

According to the author of [27], Alliance for Financial Inclusion (AFI) is collaborating with almost a hundred countries (developed and developing) to pursue financial inclusion in a large scale by designing national strategy for financial inclusion for the countries involved. The strategies involved are geared towards motivating bank account deposits, withdrawals, transfers, payment and micro credit among others: Access and usage of Bank accounts. A simple way to accomplish this, as the author of [28] observed, is by the provision of infrastructure and enabling technology that will go a long way in enhancing FI. He considers cell phone as one of the instruments that can be used which requires a dependable infrastructure related to stable network and wide coverage to operate efficiently and effectively. Additionally, such technology will reduce the cost of providing the financial services tremendously.

The refreshed inclusion strategy looks to specifically address e-payments, savings, credits, insurance and pension majorly through additional outlets. This may convert access barriers to inclusion but even for a one-to-one ATM to citizen situation without attitudinal changes in the citizen a voluntary barrier to exclusion can't be converted. And some situations do promote this voluntary exclusion. It could be a relief if one does not have to remember an account number, a Bank verification number, a sort code, a Government Integrated Financial Information System code, a secret pin number and a Tax Identification Number (TIN) just to run an account with a Bank. This is all in addition to one's employee number, National Identification Number and age, which is almost always required as if it matters in making payments. This calls for more attention while building financial inclusion policies to the issues like; financial literacy in our schools, villages, markets, motor parks and even religious institutions. Also all barriers preventing minors from enjoying financial services should be reviewed. Women should be encouraged and favoured while giving social benefits by government in rural areas.

\section{Conclusions}

FI has been confirmed to be paramount in the eradication of poverty and for the promotion of a faster economic growth. The Nigerian nation, like most other developing nations, has diligently put in place a strategy to lower financial exclusion to as low as $20 \%$ by the year 2020 . However, the two far north geopolitical zones of Nigeria have been and are still the bottleneck to higher FI. In this period of strategizing to raise the rate of inclusion, in fact, numerically more people were excluded by a higher rate of population growth. Conclusively, from our appraisal of the literature, a most potent strategy to drive faster financial inclusion would be to determine the particular proximate cause of self-exclusion for the two geopolitical zones for mitigation. The push strategy is therefore our most ardent recommendation, in congruency with the pull strategy adopted by the original National Inclusion Strategy. This, let's conclude, if adopted can drive a faster FI for all developing nations that are in a similar situation.

In the future a similar study could be undertaken empirically to determine all the factors that could have any bearing on the decision to utilise a financial facility. Such a study should dig deep at more personal level of the members of these highly excluded zones.

\section{References}

1. Demirguc-Kunt, A., Klapper, L. (2012). Measuring Financial Inclusion: The Global Findex Database. World Bank Policy Research Paper 6025. Available at: https://openknowledge. worldbank.org/handle/10986/6042

2. World Bank (2014). Global Financial Development Report 2014 Financial Inclusion. Washington: World Bank. doi: http:// doi.org/10.1596/978-0-8213-9985-9

3. Lagarde, C. (2014). Empowerment through Financial Inclusion Mexico City: Keynote address at the International Forum for Financial Inclusion. Available at: https://www.imf.org/external/ np/speeches/2014/062614a.htm

4. International Monetary Fund (2015). Financing for Develop ment - Revisiting the Monterrey Consensus. Washington: IMF Policy Paper. Available at: http://www.imf.org/external/np/ pp/eng/2015/061515.pdf

5. Triki, T., Faye, I. (Eds.) (2013). Financial Inclusion in Africa. Tunis: African Development Bank, 148. Available at: https:// www.afdb.org/fileadmin/uploads/afdb/Documents/Project-andOperations/Financial_Inclusion_in_Africa.pdf

6. Fadun, S. O. (2014). Financial inclusion; tool for poverty alleviation and income redistribution in developing countries: Evidence from Nigeria. Academic Research International, 5 (3), 137-146.

7. Abel, S., Mutandwa, L., Le Roux, P. (2018). A review of determinants of financial inclusion. International Journal of Economic and Financial Issues, 8 (3), 1-8.

8. National Financial Inclusion Strategy (2018). Central Bank of Nigeria. Available at: https://www.cbn.gov.ng/out/2019/ccd/ national\%20financial\%20inclusion\%20strategy.pdf

9. Finnegan, G. (2015). Strategies for Women's inclusion in the commonwealth. London, 52.

10. Gupta, J. (2017). Financial inclusion: A literature review of international research. International Journal of Research in Management, Economics and Commerce, 7 (11), 171-175.

11. Evans, O., Lawanson, O. (2017). A multi-sectional study of Financial Inclusion and Economic output in Nigeria. Ovidus Unoversity Annals, Economic Science series, XVIII (1), 195-204.

12. Rao, K. S., Baza, A. V. (2017). Barriers to access to and usage of financial services in Ethiopia. Business and Economic Research, 7 (1), 139-149. doi: http://doi.org/10.5296/ber.v7i1.11034

13. Aduda, J., Kalunda, E. (2012). Financial inclusion and financial sector stability with reference to Kenya: A literature review. Journal of applied Banking, 3 (6), 95-120.

14. Deepali, P. J. (2011). Financial Inclusion and Financial Literacy. BI OECD SEMINAR - Round table on the updates on Financial Education and Inclusion programmes in India. Available at: https://www.oecd.org/finance/financial-education/48303408.pdf

15. International Monetary Fund (2015). Nigeria - Selected Issues Paper. IMF Country Report 15/85. Washington. Available at: https://www.imf.org/external/pubs/ft/scr/2015/cr1585.pdf 
16. Aker, J., Wilson, K. (2013). Can mobile money be used to promote savings? Evidence from preliminary research Northern Ghana. Swift institute working paper no. 2012-003. Available at: https://swiftinstitute.org/wp-content/uploads/2012/10/ SWIFT-Institute-Working-Paper-No.-2012-003-Mobile-MoneyGhana_v7.pdf

17. Enhancing Financial Innovation \& Access (2017). Access to Financial Services in Nigeria 2008/2010/2012/2014/2016 sur vey. Available at: https://www.efina.org.ng/our-work/research/ access/

18. Nwaneri, C. (2018). Financial exclusion drops to $36.8 \%$. The Guardian Daily online. Available at: https://guardian.ng/news/ financial-exclusion-drops-to-36-8/

19. Kirfi, M. M., Abubakar, A. M., Audu, I., Baba, M. (2019). Determinants of Clients' intention to adopt Takaful services in Gombe state. Proceedings of the 5th International Academic Conference of the Institute of Chartered Accountants of Nigeria, $67-80$.

20. Agyemang-Badu, A. A., Agyei, K., Duah, E. K. (2018). Financia inclusion, poverty and income inequality: Evidence from Africa. Spiritan International Journal of Poverty Studies, 2 (2), 1-19.

21. Zins, A., Weill, L. (2016). The determinants of financial inclusion in Africa. Review of Development Finance, 6 (1), 46-57. doi: http://doi.org/10.1016/j.rdf.2016.05.001

22. Komolafe, B. (2019). CBN to increase banks' loan to deposit ratio to $70 \%$. The Vanguard Online Daily. Available at: https://www.vanguardngr.com/2019/12/breaking-cbn-toincrease-banks-ldr-to-70/

23. Fouillet, C., Morvant-Roux, S. (2015). State building in India and Mexico: Is financial inclusion a missing link? 27th conference of the Society for the Advancement of Socio-Economics. London: School of Economics and Political Science.

24. Soederberg, S. (2013). Universalising Financial Inclusion and the Securitisation of Development. Third World Quarterly, 34 (4), 593-612. doi: http://doi.org/10.1080/01436597.2013.786285
25. Arun, T., Kamath, R. (2015). Financial inclusion: Policies and practices. IIMB Management Review, 27 (4), 267-287. doi: http://doi.org/10.1016/j.iimb.2015.09.004

26. Maiyaki, A. A., Ayuba, H. (2015). Consumers' Attitude toward Islamic Insurance Services (Takaful) Patronage in Kano Metropolis, Nigeria. International Journal of Marketing Studies, 7 (2). doi: http://doi.org/10.5539/ijms.v7n2p27

27. Moya, C. A. (2017). Diseño e implementación de estrategias de inclusión financiera: Una visión desde el caso Colombiano. Dilemas actuales en torno a las Inclusiones Financieras. Guadalajara: Ciesas-Occident. Available at: https://inclusionesfinancieras.wordpress.com/

28. Rolfe, A (2017). Financial inclusion - Addressing the unbanked in developing countries. Daily News. Available at: https:// www.paymentscardsandmobile.com/addressing-unbanked-underbanked-developing-countries

Abubakar Adamu Magaji, Doctor of Business Administration, Academician, Head of Department of Business Administration, Federal University Dutse, Jigawa, Nigeria, ORCID: https://orcid.org/00000001-7726-1696, e-mail: magajiaa@fud.edu.ng

Daneji Bashir Ahmad, Doctor of Banking and Finance, Academician Department of Banking and Finance, Modibbo Adama University of Technology Yola, Adamawa, Nigeria, ORCID: https://orcid.org/ 0000-0001-5709-8334,e-mail: badaneji@yahoo.com

Muhammed Ahmed Ibrahim, Doctor of Banking and Finance, Academician, Head of Department of Banking and Finance, Federal University Dutse, Jigawa, Nigeria, ORCID: https://orcid.org/00000002-5505-1417, e-mail: ahmed.im@fud.edu.ng

Chekene Imam-Ahmad Buba, Academician, Department of Business Administration, Federal University Dutse, Jigawa, Nigeria, ORCID: https:/ orcid.org/0000-0001-5058-5084, e-mail:Imam1234@gmail.com 